\title{
Effect of Potting Media and Watering Frequency on Dry Matter Production and Distribution of Seedling of Korarima (Aframomum cororima (Braun) P.C.M. Jansen)
}

\author{
Jafer Dawid \\ Jimma Agricultural Research Center, Jimma Ethiopia, P.O.Box 192, Jimma, Ethiopia.
}

\begin{abstract}
Korarima (Aframomum korarima) is native crop to Ethiopia, herbaceous, perennial and aromatic spice. Production is much lower mainly due to constraints such as lack of improved variety, Poor agronomic practices. Thus, the current study was conducted to determining Biomass Production and Distribution on Seedling of Korarima under media and watering frequency at the Jimma Research Center, southwest Ethiopia. The treatments included Soil media seven levels (Forest, Top , Forest : Top , Forest : Compost, Top : Compost, Forest : Top soil : compost, Top : Compost ( 3:1)) and Watering frequency four levels (every day, two, three \& four). A split plot design with three replications, Soil media and Watering frequency were assigned as main and sub-plot, respectively. Four months old seedlings were used to require the media and watering frequency and to record dry mass of leaves, stem, and root growth. Each organ was separately oven-dried and total dry matter production and allocation patterns were measured analyzed. The results described highly significant differences between the soil media and watering frequency for most of the parameters considered. As a result, root, leaf, stem, shoot and total biomass assimilation and partitioning. The highest score of DM weight was obtained under Korarima seeds sown in mixed top soil and compost soil media combination in 3:1 ratio and blended of forest soil, top soil and compost in 1:1:1 ratio with watering frequency every two days or every three days shown significant leaf, stem, shoot and root dry matter weight $(g)$, respectively. Watering frequency every four days shown low dry matter weight. $(g)$. In general, interaction effect of the factors showed highly significant $(p<0.01)$ variation in terms of the total dry matter share varied for the seedling growth parts $($ root $=17.61 \%$, leaf $=48.66 \%$, stem $=33.73 \%$ and whole shoot $=82.29 \%)$. It can be concluded that watering frequency every three or two days and media of top soil and compost combinations improved both dry mass and dry matter partitioning of seedling.
\end{abstract}

Keywords: Aframomum cororima, Korarima seedling, Soil Media, Watering days, dry-matter partitioning.

\section{INTRODUCTION}

Korarima (Aframomum corrorima (Braun) P.C.M. Jansen) is herbaceous, perennial and aromatic species classified in the monocotyledonous family Zingiberaceae, native to Ethiopia, there could exist high genetic diversity in the country (Girma et al., 2008). The plant consists of an underground rhizome, a pseudo stem, and several broad leaves and resembles Elettaria species morphologically. Mature korarima can reach a height of 1-2 m. It sets seed after 3-5 years of planting depending on the planting materials used and it continue to bear seeds for a number of decades (Eyob et al., 2009). The plant is propagated both by seeds and rhizome parts (Ravindran et al., 2002).

It is economically important species used as traditional medicine and food preservative, to flavor coffee and bread, as source of income from local and export markets, for soil conservation and as substitute of Indian cardamom (Eyob et al., 2007). It is a shade loving plant that grows in almost the same habitats as wild Arabica coffee in high rain forests areas of the country (Jansen, 2002).

Nursery rooting media mixtures play a key role in improving soil physical and chemical properties and, thereby, increasing seedling growth and penetrating capacity of roots, suitable environment with proper aeration, sufficient water and nutrient supply was offered by the medium, excellent root system developed, which, in turn, resulted in luxurious growth of plants (Neelam and Ishtiaq, 2001)

The biomass of a plant about $95 \%$ are derived from the carbohydrates manufactured in the green parts by the process of photosynthesis and the remaining 5\% come from mineral elements absorbed by the roots and the capacity of the plant to produce carbohydrate depends mainly on the total green (mainly leaf) area engaged in photosynthesis and the net photosynthetic rate per unit green surface area, and dry matter production in any crop depends upon leaf area index, structure of the canopy, 
photosynthetic rate per unit of leaf area and strength of the metabolic sinks in attracting assimilates(Taye Kufa, 2012).

Nutrient proportions can also be important in affecting the distribution of dry matter amongst plant organs. In studies where the growth of birch seedlings has been manipulated by varying the flux of $\mathrm{Mg}$, the allocation of dry matter between roots and shoots has been affected by the amount of $\mathrm{N}$ absorbed (A. James et al., 1996). Where excess uptake of $\mathrm{N}$ was restricted (but where plant growth rate was still being limited by $\mathrm{Mg}$ supply), the fraction of plant dry matter in the root was greater than in plants with larger amounts of excess $\mathrm{N}$. This may indicate a central role for nitrogen in modifying the distribution of dry matter amongst plant organs, even where other nutrients (at least $\mathrm{Mg}$ ) are limiting the growth rate of the plant and determining the general category of dry matter distribution.

Dry matter production in any crop depends upon the leaf area index (LAI), the structure of the canopy, the photosynthetic rate per unit of leaf area, and the strength of the metabolic sinks in attracting assimilates, which is particularly important in coffee and also for other crops like korarima where the fruits have been shown to be the dominant sinks (CHB, 1987)

If crops are to perform optimally, they must have regulatory mechanisms to ensure that Photosynthetic and nitrogen assimilates are allocated to various parts of plant in ratios that provide well balanced whole plant functions. For example, during the vegetative growth stage, assimilates should be distributed to leaf production and production of new roots in ratios that provide a balance between the capacity for photosynthesis and the capacity for acquisition of mineral nutrients and water. (Setter, 1992)

A recent study on woody and herbaceous species indicated that changes in root: shoot ratio or the temporary accumulation of reserves in the stem is accompanied by alterations in nitrogen and carbon metabolism, which affects dry matter partitioning (Chaves et al., 2008)

It has often been assumed that the net result of growth responses to decreased nutrient availability is not only a decrease in plant growth rate, but a shift in the distribution of dry matter in favor of root biomass (A. James et al., 1996).

The accumulation of dry matter and distribution between roots and shoots in seedlings developed different, because in each condition, the amount of nutrients available and water to the seedling is different. Seedlings show marked differences in morphology and proportions of distribution and allocation of dry matter in the structures and root that are formed (Ericsson, 1995)..

In Ethiopia, there is limited information about the soil media and water on dry matter production and their distribution into different plant parts of the crop spice. Therefore, the objective of this study was the effect of different nursery media compositions and watering frequency on dry matter production and distribution of korarima seedlings.

\section{Materials AND Methods}

The experiment was conducted at a common nursery garden of the Jimma Research Center, southwest Ethiopia (latitude of $7^{\circ}, 46^{\prime \prime} \mathrm{N}$, and longitude of $30^{\circ}, 50^{\circ} \mathrm{E}, 1750 \mathrm{~m}$.a.s.l). The average maximum and minimum air temperatures are $26.3^{\circ} \mathrm{C}$ and $11.6^{\circ} \mathrm{C}$, respectively. The area receives adequate amount of rain- fall with an average rainfall of $1530 \mathrm{~mm}$ per annum, with $66 \%$ of average relative humidity.

Experimental Treatments and Design

Fully ripened bold red capsules of local land race of korarima (Jimma) were harvested and fresh capsules were split open and seeds were extracted from the capsules. The seven planting growth soil media consisting of forest soil, top soil and compost prepared from decomposed grass, coffee pulp, top soil and cow dung at the respective proportion $(\mathrm{v} / \mathrm{v})$ and firmly filled in to black polythene bag of $16 \mathrm{~cm}$ wide and $22 \mathrm{~cm}$ length. A single experimental unit (plot) consisted of 12 pots were arranged in rectangle fashion $(3 \times 4)$ on nursery bed. Then, uniform and healthy seeds were selected and the prepared korarima seeds were sown in each pot. The recommended post-sowing nursery operations were applied (IAR,(1996) and the seedlings were uniformly managed under partial shade conditions and irrigated based on the treatments. When it rains, experimental units (plots) were covered by plastic sheet. Four months after sowing the central four korarima seedlings were used to record destructive growth parameters for each treatment. These include dry weight of leaves, stem, and root. The roots were immersed and washed in clean water to remove adhering soil. Subsequently, each 
plant part was separately oven-dried at $70^{\circ} \mathrm{C}$ until a constant weight obtained and weighed using a sensitive balance. Finally, total dry matter production and allocation patterns were determined in seedlings of korarima.

A split plot design of three replication was employed with seven soil media(forest soil alone, top soil alone, and mixture of forest and top soil in 1:1 ratio, forest soil and compost in 1:1 ratio, top soil and compost in 1:1, forest soil, top soil and compost in 1:1:1 ratio, and top soil and compost in 3:1 ratio) and four watering frequency treatments (every day, every two days, every three days and every four days) were assigned as main plot and subplots, respectively.

Data Analysis

The collected data were processed and the statistical analysis was accomplished using SAS computer software Version 9.2 (SAS, 2008).. The analysis of variance (ANOVA) was computed for each growth variable considered. Moreover, significant differences among the treatments were compared using Fisher's Least Significance Difference (LSD) at $<5 \%$ probability level.

\section{RESULTS AND DISCUSSION}

\section{Dry Matter Production}

\section{Leaf dry weight}

Interaction of soil media and watering frequency on leaf dry weight was highly significant different ( $p<0.01$ ). The response indicating that some had the same response to interaction effects of soil media and watering frequency in dry matter accumulation in their leaf weight $(\mathrm{g})$ for treatment top soil and compost mixture at 3:1 ratio and watering frequency every two days $(1.590 \mathrm{~g})$ maximum dry weight per plant was recorded. Similarly, forest soil media and watering frequency every two days, top soil media and watering frequency every three days and top soil and compost mixture at 1:1 ratio and watering frequency every three days treatments exhibited higher mean values $(1.303 \mathrm{~g}),(1.283 \mathrm{~g})$ and $(1.403 \mathrm{~g})$ at four months growth of seedling stage, while top soil and compost mixture at 3:1 ratio and watering frequency every four days treatment showed the minimum value of $(0.527 \mathrm{~g})$ (Table 1$)$. The minimum value observed was because of the soil less frequent irrigated and also physical and chemical character of the soil medium support the watering frequency of one and two days interval. While at growth stage increase the frequency of the water may decrease at normal condition. The finding similar with work of Tesfaye et al., (2013) frequent watering resulted in higher rate of shoot growth with greater leaf area, stem diameter, leaf and stem dry weight and height of seedlings.

\section{Pseudo Stem Dry Weight}

Interaction of soil media and watering frequency on stem dry weight $(\mathrm{g})$ were highly significant different $(\mathrm{p}<0.01)$ observed and maximum stem dry weight per plant were recorded from treatment top soil and compost mixture at 3:1 or 1:1 ratio or blended forest and compost 1:1 ratio watering frequency every two days $(1.33, \mathrm{~g}, 1.25 \mathrm{~g})$, and minimum values from treatments forest soil or blended forest, top soil and compost 1:1:1 ratio or top soil and compost mixture 3:1 ratio and watering frequency every four days $(0.40 \mathrm{~g}, 0.39 \mathrm{~g}$ ) (Table 1). This finding is observed due to forest soil media alone with applying daily watering frequency up to two months increase the weight of leaf and stem but after this stage the media not increase the weight even though the frequency as it is, this may be due to nutrient content of the media. On the other hand, media with compost soil combination shown weight increase. This finding similar with work of (Simon A et al., 2011) Considering water availability, labor costs and time involved and based on the present results, nursery to irrigate korarima seedlings every two days interval with compost soil combination under the prevailing conditions.

\section{Shoot Dry Weight}

The highest shoot dry weight $(\mathrm{g})$ were recorded from treatment top soil and compost mixture at 3:1 ratio and watering frequency every two days $(2.92 \mathrm{~g})$ at four months of seedling growth stage after sowing. On the other hand, the least shoot weight (g) was observed from top soil and compost mixture at 3:1 ratio and watering frequency every four days treatment $(0.93 \mathrm{~g})$ at four months of growth stages or periods after sowing (Table 1). This might be because of the interaction of the two factors enough to bring a significant difference. The result is similar with report of Raviraja Shetty (2014) the 
increased fresh and dry weight of leaf, stem, aerial part and total plant may be due to superiority of the treatment which resulted in vigorous vegetative growth parameters.

\section{Root Dry Weight}

Interaction of soil media and watering frequency on root dry weight $(\mathrm{g})$ was differed significantly $(\mathrm{p}<$ 0.05). Among the treatments tested, highest root weight per seedling were recorded from forest soil and compost mixture at 1:1 ratio and watering frequency every two days treatment or blended of forest soil, top soil and compost in 1:1:1 ratio and watering frequency every two days treatments, which were $0.633 \mathrm{~g}$ and $0.600 \mathrm{~g}$. On the other hand, top soil and compost mixture at $3: 1$ ratio and watering frequency every three or four days treatment gave the lowest root weight $0.093 \mathrm{~g}, 0.147 \mathrm{~g}$ (Table 1). From the result obtained with blended soil media due to watering frequency increase the dry matter of the root was increased with less watering frequency the root dry weight decreased..The result similar with work of Mohammed (2004) growth and the distribution of the root of coffee seedling expressed as root length and root density and root weight were further enhanced by water frequency of water but decreased with limited supply.

Table1. Interaction effects of soil media and watering frequency on dry wt of leaf, pseudo stem, root and total dry wt. of Korarima seedling

\begin{tabular}{|c|c|c|c|c|}
\hline Treatments & $\begin{array}{l}\text { Leaf } \\
w t(g)\end{array}$ & $\begin{array}{l}\text { Stem } \\
\mathrm{wt}(\mathrm{g})\end{array}$ & $\begin{array}{l}\text { Shoot } \\
\mathrm{wt}(\mathrm{g})\end{array}$ & $\begin{array}{l}\text { Root } \\
\text { wt(g) }\end{array}$ \\
\hline Forest soil X WF Every 1 Day & $1.000^{\mathrm{c}-\mathrm{g}}$ & $0.49 \mathrm{j}-1$ & $1.49^{\mathrm{g}-\mathrm{k}}$ & $0.453^{\mathrm{b}-\mathrm{d}}$ \\
\hline Forest soil X WF Every 2 Days & $1.303^{\mathrm{a}-\mathrm{c}}$ & $0.97 \mathrm{bc}$ & $2.27^{\mathrm{bc}}$ & $0.470^{\mathrm{bc}}$ \\
\hline Forest soil X WF Every 3 Days & $0.870^{\mathrm{e}-\mathrm{i}}$ & $0.52 \mathrm{~h}-\mathrm{k}$ & $1.40^{\mathrm{h}-\mathrm{k}}$ & $0.320^{\mathrm{f}-\mathrm{h}}$ \\
\hline Forest soil X WF Every 4 Days & $0.710^{\mathrm{g}-\mathrm{j}}$ & 0.401 & $1.11^{\mathrm{kI}}$ & $0.290^{\mathrm{g}-1}$ \\
\hline Top soil X WF Every 1 Day & $1.003^{\mathrm{c}-\mathrm{g}}$ & $0.59 \mathrm{~g}-\mathrm{j}$ & $1.59^{\mathrm{g}-\mathrm{j}}$ & $0.367^{\mathrm{d}-\mathrm{g}}$ \\
\hline Top soil X WF Every 2 Days & $0.983^{\mathrm{c}-\mathrm{g}}$ & $0.58 \mathrm{~g}-\mathrm{j}$ & $1.56^{\mathrm{g}-\mathrm{j}}$ & $0.437^{\mathrm{b}-\mathrm{e}}$ \\
\hline Top soil X WF Every 3Days & $1.283^{\mathrm{a}-\mathrm{d}}$ & $0.86 \mathrm{c}-\mathrm{e}$ & $2.14^{\mathrm{b}-\mathrm{e}}$ & $0.313^{\mathrm{f}-1}$ \\
\hline Top soil X WF Every 4 Days & $1.157^{\mathrm{b}-\mathrm{e}}$ & $0.59 \mathrm{~g}-\mathrm{j}$ & $1.75^{\mathrm{e}-\mathrm{h}}$ & $0.300^{\mathrm{g}-1}$ \\
\hline Forest : Top soil X WF Every 1 Day & $0.950^{\mathrm{d}-\mathrm{h}}$ & $0.63 \mathrm{f}-\mathrm{h}$ & $1.58^{\mathrm{g}-\mathrm{j}}$ & $0.283^{\mathrm{g}-\mathrm{i}}$ \\
\hline Forest : Top soil X WF Every 2 Days & $1.147^{\mathrm{b}-\mathrm{f}}$ & $0.75 \mathrm{ef}$ & $1.89^{\mathrm{c}-\mathrm{g}}$ & $0.493^{b}$ \\
\hline Forest :Top soil X WF Every 3 Days & $0.75^{\mathrm{g}-\mathrm{j}}$ & $0.49 \mathrm{i}-1$ & $1.24^{\mathrm{i}-\mathrm{I}}$ & $0.350^{\mathrm{e}-\mathrm{g}}$ \\
\hline Forest : Top soil X WF Every 4 Days & $0.630^{\mathrm{h}-\mathrm{j}}$ & $0.45 \mathrm{kl}$ & $1.08^{\mathrm{kI}}$ & $0.220^{\mathrm{ij}}$ \\
\hline Forest : Compost X WF Every 1 Day & $1.193^{\mathrm{b}-\mathrm{e}}$ & $0.60 \mathrm{~g}-\mathrm{j}$ & $1.80^{\mathrm{d}-\mathrm{h}}$ & $0.337^{\mathrm{f}-\mathrm{h}}$ \\
\hline Forest : Compost $\mathrm{X}$ WF Every 2 Days & $0.777^{\mathrm{g}-\mathrm{j}}$ & $1.25 \mathrm{a}$ & $2.03^{\mathrm{c}-\mathrm{f}}$ & $0.633^{\mathrm{a}}$ \\
\hline Forest :Compost X WF Every 3 Days & $0.747^{\mathrm{g}-\mathrm{j}}$ & $0.65 f g$ & $1.4^{\mathrm{h}-\mathrm{k}}$ & $0.243^{\text {hi }}$ \\
\hline Forest : Compost X WF Every 4Days & $0.813^{\mathrm{f}-\mathrm{j}}$ & $0.56 \mathrm{~g}-\mathrm{k}$ & $1.37^{\mathrm{h}-\mathrm{k}}$ & $0.347^{\mathrm{e}-\mathrm{g}}$ \\
\hline Top : Compost X WF Every 1 Day & $1.137^{\mathrm{b}-\mathrm{f}}$ & $1.09 \mathrm{~b}$ & $2.22^{\mathrm{b}-\mathrm{d}}$ & $0.490^{\mathrm{b}}$ \\
\hline Top: Compost X WF Every 2 Days & $1.180^{\mathrm{b}-\mathrm{e}}$ & $1.33 \mathrm{a}$ & $2.51^{\mathrm{b}}$ & $0.413^{\mathrm{b}-\mathrm{f}}$ \\
\hline Top: Compost X WF Every 3 Days & $1.403^{\mathrm{ab}}$ & $0.62 \mathrm{~g}-\mathrm{i}$ & $2.02^{\mathrm{c}-\mathrm{f}}$ & $0.283^{\mathrm{g}-1}$ \\
\hline Top : Compost X WF Every 4Days & $1.040^{\mathrm{e}-\mathrm{g}}$ & $0.59 \mathrm{~g}-\mathrm{j}$ & $1.63^{\mathrm{f}-1}$ & $0.350^{\mathrm{e}-\mathrm{g}}$ \\
\hline Forest : Top : Compost X WF Every 1 Day & $0.697^{\mathrm{g}-\mathrm{j}}$ & $0.49 \mathrm{j}-1$ & $1.19^{j-1}$ & $0.347^{\mathrm{e}-\mathrm{g}}$ \\
\hline $\begin{array}{r}\text { Forest : Top: Compost X WF Every } 2 \\
\text { Days }\end{array}$ & $1.24^{\mathrm{b}-\mathrm{d}}$ & $0.91 \mathrm{~cd}$ & $2.15^{\mathrm{b}-\mathrm{e}}$ & $0.600^{\mathrm{a}}$ \\
\hline $\begin{array}{r}\text { Forest : Top: Compost X WF Every } 3 \\
\text { Days }\end{array}$ & $1.267^{\mathrm{b}-\mathrm{d}}$ & $0.63 \mathrm{f}-\mathrm{h}$ & $1.90^{\mathrm{c}-\mathrm{g}}$ & $0.303^{\mathrm{g}-\mathrm{i}}$ \\
\hline $\begin{array}{r}\text { Forest : Top : Compost X WF Every } 4 \\
\text { Days }\end{array}$ & $0.737^{\mathrm{g}-\mathrm{j}}$ & 0.391 & $1.12^{\mathrm{kl}}$ & $0.35^{\mathrm{e}-\mathrm{g}}$ \\
\hline 3Top : 1 Compost X WF Every 1 Day & $1.220^{b-d}$ & $0.80 \mathrm{de}$ & $2.02^{\mathrm{c}-\mathrm{f}}$ & $0.380^{\mathrm{c}-\mathrm{g}}$ \\
\hline 3 Top: 1 Compost $\mathrm{X}$ WF Every 2 Days & $1.590^{\mathrm{a}}$ & $1.33 \mathrm{a}$ & $2.92^{\mathrm{a}}$ & $0.477^{b}$ \\
\hline 3 Top : 1 Compost X WF Every 3Days & $0.557^{\mathrm{ij}}$ & $0.61 \mathrm{~g}-\mathrm{j}$ & $1.17^{\mathrm{j}-1}$ & $0.093^{\mathrm{k}}$ \\
\hline 3Top : 1Compost X WF Every 4 Days & $0.527^{j}$ & 0.391 & $0.93^{1}$ & $0.147^{\mathrm{jk}}$ \\
\hline LSD 5\% & 0.29 & 0.12 & 0.66 & 0.08 \\
\hline $\mathrm{Cv} \%$ & 17.67 & 10.89 & 13.46 & 14.38 \\
\hline
\end{tabular}

Mean values followed by the same letter(s) with in a column are not significantly different at $\mathrm{P}<0.05$

\section{Root to Shoot Ratio Dry Weight}

Among the interaction effects of soil media and watering frequency on Root to shoot ratio of treatments tested, the highest root to shoot ratio per plant was recorded from treatment forest soil and compost mixture at 1:1 ratio and watering frequency every two days, a blend of forest soil, top soil 
and compost in 1:1:1 ratio and watering frequency every four days treatments, which were, $0.314 \mathrm{~g}$ and $0.313 \mathrm{~g}$ at growth stages of four months after sowing. On the other hand, top soil and compost mixture at 3:1 ratio and watering frequency every three days treatment gave the lowest root to shoot ratio values of $0.0800 \mathrm{~g}$ per seedling (Table 2). The result observed was may be due to the combination of the soil ability can conceive water and supply nutrient that enhanced growth of root and shoot, and that increased the ratio of dry weight . It was also shown that the amount of root growth and shoot were also influenced by the amount of nutrients in the soils and it has also been indicated that the root system seems and its effectiveness in obtaining water and nutrients from the soil. Furthermore, the porosity and pore size distribution can give important on soil structure as pores determine the various soil physical properties important to plant growth. In addition a nutrient deficient soil media resulted low root to shoot ratio at this stage. It can be, therefore, suggested that watering frequency should consider media composition and growth stages of seedlings so as to produce high quality seedlings with right proportion of shoot and root growth that can ensure maximum field establishments. The result similar with report of Taye et al., (2008) shoot and root dry matter yield were significantly influenced by watering treatment where maximum values were measured at a watering interval of days and reduced results were noticed with more delayed watering.

Table 2. Interaction effect of soil media and watering frequency on Root to Shoot ratio dry weight

\begin{tabular}{|c|c|c|c|c|c|c|c|}
\hline \multirow[t]{2}{*}{ Watering Frequency } & \multicolumn{7}{|c|}{ Soil media } \\
\hline & Forest & Top & $1 \mathrm{~F}: 1 \mathrm{~T}$ & 1F:1C & $1 \mathrm{~T}: 1 \mathrm{C}$ & 1F:1T:1C & $3 \mathrm{~T}: 1 \mathrm{C}$ \\
\hline Every 1 Day & $0.306^{\mathrm{ab}}$ & $0.231^{\mathrm{d}-\mathrm{f}}$ & $0.176^{\mathrm{g}-k}$ & $0.18^{\mathrm{r}-\mathrm{k}}$ & $0.221^{\mathrm{d}-\mathrm{g}}$ & $0.291^{\mathrm{a}-\mathrm{c}}$ & $0.189^{\mathrm{t}-\mathrm{k}}$ \\
\hline Every 2Days & $0.208^{e-i}$ & $0.279^{\mathrm{a}-\mathrm{c}}$ & $0.290^{b-d}$ & $0.314^{\mathrm{a}}$ & $0.165^{i-k}$ & $0.277^{\mathrm{a}-\mathrm{c}}$ & $0.162^{i-k}$ \\
\hline Every 3Days & $0.230^{\mathrm{d}-\mathrm{f}}$ & $0.149^{k}$ & $0.288^{\mathrm{a}-\mathrm{c}}$ & $\begin{array}{l}0.177^{--} \\
k\end{array}$ & $0.145^{\mathrm{k}}$ & $0.160^{\mathrm{i}-\mathrm{k}}$ & $0.080^{1}$ \\
\hline Every 4Days & $0.262^{\mathrm{b}-\mathrm{d}}$ & $0.178^{\mathrm{h}-\mathrm{k}}$ & $0.206^{e-j}$ & $\begin{array}{l}0.256^{\mathrm{c}-} \\
\mathrm{e}\end{array}$ & $0.215^{\mathrm{d}-\mathrm{h}}$ & $0.313^{\mathrm{a}}$ & $0.159^{\mathrm{jk}}$ \\
\hline LSD 5\% & \multicolumn{7}{|l|}{0.05} \\
\hline $\mathrm{Cv} \%$ & 11.56 & & & & & & \\
\hline
\end{tabular}

Mean values followed by the same letter(s) are not significantly different at $\mathrm{P}<0.05$

$\mathrm{F}=$ Forest, $\mathrm{T}=\mathrm{Top}, \mathrm{C}=$ Compost

\section{Dry Matter (DM) \% Distribution}

Interaction of soil media and watering frequency on leaf, stem and root and shoot dry matter partitioning were highly significant different $(\mathrm{p}<0.01)$ for Korarima seedling. The greatest proportion of DM was found in the leaf (Table 3), which ranged from 29.97\% (lowest) for treatment forest soil and compost mixture at 1:1 ratio and watering frequency every two days to $60.33 \%$ (highest) for treatment top soil and compost mixture at 1:1 ratio and watering frequency every three days. The result is in agreement with Taye (2012) who reported that for maximum rate of production of dry matter within the plant as a whole it is important that a high proportion of assimilates as possible should be returned to the leaf tissue, which will further increase the productive capacity of the plant, and that expenditure of dry matter on the rest of the plant should be no more than is required to efficiently support the leaves and supply sufficient mineral nutrients and water.

The other part stem had 25.13 to $48.81 \%$ of their DM for treatment top soil and compost mixture at $3: 1$ ratio and watering frequency every three days or forest soil and compost mixture at 1:1 ratio and top soil and compost mixture at 1:1 ratio watering frequency every two days (Table 3 ). The lowest was for treatment forest soil with watering frequency every day. The result sustained by report of Wintgens, J.N. (2004) assimilate utilization may be limited by various external factors including temperature, and the supply of water and mineral elements

Root contained the lowest amount of DM, the interaction of different levels of soil media and watering frequency significant impact on the root dry \%t of korarima seedlings. However, the highest DM \% (23.86 or $23.79 \%)$ and the lowest DM (7.39\%) results were recorded from those treatments that blended of forest soil and compost in 1:1 ratio and watering frequency every two days or blended of forest soil, top soil and compost in 1: 1:1 ratio and watering frequency every four days and treatment of top soil and compost mixture at 3:1 ratio and watering frequency every three days, respectively (Table 3). This finding is consistent with the results of R. Bras et al. (1995) that the 
amount of biomass allocated to leaves was significantly higher in watered soil. Low water availability decreased allocation of biomass to support tissues in Ipomoea.

The amount of biomass allocated to shoot was significantly higher in soil media and watering frequency .The highest mean values of $92.61 \%$ was recorded for top soil and compost mixture at 3:1 ratio and watering frequency every three days (Table 3$)$. The lowest value recorded $(76.25 \%, 76.14$ $\%$ ) for blended of forest soil, top soil and compost in 1:1:1 ratio and mixture of forest soil and compost in 1:1 ratio and watering frequency every four and two days, respectively. Similarly, Taye (2012) pointed out that the higher assimilate amounts stored in the shoot part of shaded seedlings, though the allocation to the root part was low.

Table 3. Interaction effects of soil media and watering frequency on DM \% Distribution of leaf, stem, root and Shoot of Korarima seedling.

\begin{tabular}{|c|c|c|c|c|}
\hline Treatment & Leaf & Stem & Root & Shoot \\
\hline Forest soil X WF Every 1 Day & $51.43^{\mathrm{b}-\mathrm{e}}$ & $25.13^{\mathrm{k}}$ & $23.44^{\mathrm{ab}}$ & $76.56^{\mathrm{kI}}$ \\
\hline Forest soil X WF Every 2 Days & $47.61^{\mathrm{d}-\mathrm{h}}$ & $35.21^{\mathrm{c}-\mathrm{e}}$ & $17.18^{\mathrm{f}-1}$ & $82.82^{\mathrm{d}-\mathrm{g}}$ \\
\hline Forest soil X WF Every 3 Days & $50.73^{\mathrm{c}-\mathrm{f}}$ & $30.55^{\mathrm{e}-\mathrm{j}}$ & $18.72^{\mathrm{d}-\mathrm{f}}$ & $81.28^{\mathrm{g}-\mathrm{i}}$ \\
\hline Forest soil X WF Every 4 Days & $51.27^{\mathrm{c}-\mathrm{f}}$ & $28.02^{\mathrm{h}-\mathrm{k}}$ & $20.71^{\mathrm{b}-\mathrm{d}}$ & $79.29^{1-k}$ \\
\hline Top soil X WF Every 1 Day & $51.17^{\mathrm{c}-\mathrm{f}}$ & $30.07^{\mathrm{f}-\mathrm{j}}$ & $18.76^{\mathrm{d}-\mathrm{f}}$ & $81.24^{\mathrm{g}-1}$ \\
\hline Top soil X WF Every 2 Days & $49.25^{\mathrm{d}-\mathrm{g}}$ & $28.96^{\mathrm{f}-\mathrm{k}}$ & $21.79^{\mathrm{a}-\mathrm{c}}$ & $78.21^{\mathrm{j}-1}$ \\
\hline Top soil X WF Every 3Days & $51.95^{\mathrm{b}-\mathrm{d}}$ & $35.13^{\mathrm{c}-\mathrm{e}}$ & $12.92^{\mathrm{k}}$ & $87.08^{b}$ \\
\hline Top soil X WF Every 4 Days & $56.23^{\mathrm{a}-\mathrm{c}}$ & $29.15^{\mathrm{f}-\mathrm{k}}$ & $14.62^{\mathrm{i}-\mathrm{k}}$ & $85.38^{\mathrm{b}-\mathrm{d}}$ \\
\hline Forest : Top soil X WF Every 1 Day & $51.41^{b-f}$ & $33.69^{\mathrm{d}-\mathrm{f}}$ & $14.90^{\mathrm{i}-\mathrm{k}}$ & $85.10^{b-d}$ \\
\hline Forest : Top soil X WF Every 2 Days & $48.15^{\mathrm{d}-\mathrm{g}}$ & $31.29^{\mathrm{e}-\mathrm{j}}$ & $20.57^{\mathrm{cd}}$ & $79.43^{\mathrm{ij}}$ \\
\hline Forest :Top soil X WF Every 3 Days & $46.68^{\mathrm{d}-\mathrm{h}}$ & $31.00^{\mathrm{e}-\mathrm{j}}$ & $22.31^{\mathrm{a}-\mathrm{c}}$ & $77.69^{j-1}$ \\
\hline Forest : Top soil X WF Every 4 Days & $47 . .99^{\mathrm{d}-\mathrm{h}}$ & $34.93^{\mathrm{c}-\mathrm{e}}$ & $17.08^{\mathrm{f}-\mathrm{i}}$ & $82.92^{\mathrm{d}-\mathrm{g}}$ \\
\hline Forest : Compost X WF Every 1 Day & $55.91^{\mathrm{a}-\mathrm{c}}$ & $28.25^{\mathrm{h}-\mathrm{k}}$ & $15.84^{\mathrm{g}-\mathrm{j}}$ & $84.16^{\mathrm{c}-\mathrm{f}}$ \\
\hline Forest : Compost X WF Every 2 Days & $29.97^{j}$ & $47.17^{\mathrm{a}}$ & $23.86^{\mathrm{a}}$ & $76.14^{1}$ \\
\hline Forest :Compost X WF Every 3 Days & $44.44^{\mathrm{g}-\mathrm{i}}$ & $40.59^{b}$ & $14.97^{\mathrm{h}-\mathrm{k}}$ & $85.03^{\mathrm{b}-\mathrm{e}}$ \\
\hline Forest : Compost X WF Every 4Days & $47.53^{\mathrm{d}-\mathrm{h}}$ & $32.35^{\mathrm{e}-\mathrm{h}}$ & $20.12^{\mathrm{c}-\mathrm{e}}$ & $79.88^{\mathrm{h}-j}$ \\
\hline Top : Compost X WF Every 1 Day & $41.9^{\mathrm{hi}}$ & $40.05^{\mathrm{b}}$ & $18.04^{\mathrm{d}-\mathrm{g}}$ & $81.95^{\mathrm{f}-1}$ \\
\hline Top: Compost X WF Every 2 Days & $40.3^{i}$ & $45.52^{\mathrm{a}}$ & $14.17^{\mathrm{jk}}$ & $85.83^{\mathrm{bc}}$ \\
\hline Top: Compost X WF Every 3 Days & $60.15^{\mathrm{a}}$ & $27.25^{\mathrm{i}-\mathrm{k}}$ & $12.6^{\mathrm{k}}$ & $87.40^{\mathrm{b}}$ \\
\hline Top : Compost X WF Every 4Days & $52.44^{\mathrm{b}-\mathrm{d}}$ & $29.88^{\mathrm{f}-\mathrm{k}}$ & $17.63^{\mathrm{e}-\mathrm{h}}$ & $82.33^{\mathrm{e}-\mathrm{h}}$ \\
\hline Forest : Top : Compost X WF Every 1 Day & $45.57^{\mathrm{e}-\mathrm{i}}$ & $31.89^{\mathrm{e}-\mathrm{i}}$ & $22.55^{\mathrm{a}-\mathrm{c}}$ & $77.45^{j-1}$ \\
\hline $\begin{array}{l}\begin{array}{l}\text { Forest : Top: Compost } \\
\text { Days }\end{array} \\
\end{array}$ & $45.22^{\mathrm{f}-\mathrm{i}}$ & $33.05^{\mathrm{e}-\mathrm{g}}$ & $21.73^{\mathrm{a}-\mathrm{c}}$ & $77.45^{\mathrm{j}-\mathrm{I}}$ \\
\hline $\begin{array}{l}\begin{array}{l}\text { Forest : Top: Compost } \\
\text { Days }\end{array} \\
\end{array}$ & $57.44^{\mathrm{ab}}$ & $28.77^{\mathrm{g}-\mathrm{k}}$ & $13.79^{\mathrm{jk}}$ & $86.21^{\mathrm{bc}}$ \\
\hline $\begin{array}{l}\text { Forest : Top : Compost } \quad \text { X WF Every } 4 \\
\text { Days }\end{array}$ & $49.55^{\mathrm{d}-\mathrm{g}}$ & $26.66^{\mathrm{jk}}$ & $23.79^{\mathrm{a}}$ & $76.21^{1}$ \\
\hline 3Top : 1 Compost X WF Every 1 Day & $50.73^{\mathrm{c}-\mathrm{f}}$ & $33.40^{\mathrm{e}-\mathrm{g}}$ & $15.87^{\mathrm{g}-\mathrm{j}}$ & $84.13^{\mathrm{c}-\mathrm{f}}$ \\
\hline 3 Top: 1 Compost $\mathrm{X}$ WF Every 2 Days & $46.74^{\mathrm{d}-\mathrm{h}}$ & $39.34^{\mathrm{bc}}$ & $13.92^{\mathrm{jk}}$ & $86.08^{\mathrm{bc}}$ \\
\hline 3 Top : 1 Compost X WF Every 3Days & $43.81^{\mathrm{g}-\mathrm{i}}$ & $48.81^{\mathrm{a}}$ & $7.39^{1}$ & $92.61^{\mathrm{a}}$ \\
\hline 3Top : 1Compost X WF Every 4 Days & $48.04^{\mathrm{d}-\mathrm{h}}$ & $38.29^{\mathrm{b}-\mathrm{d}}$ & $13.67^{\mathrm{jk}}$ & $86.33^{\mathrm{bc}}$ \\
\hline LSD 5\% & 7.71 & 8.7 & 9.53 & 2.04 \\
\hline $\mathrm{Cv} \%$ & 6.14 & 4.8 & 2.74 & 2.74 \\
\hline
\end{tabular}

Mean values followed by the same letter(s) with in a column are not significantly different at $\mathrm{P}<0.05$

\section{CONCLUSION}

According to the results obtained mixed top and compost soil media in 3:1>1:1 ratios > blended forest and top soil with compost media in 1:1:1 and watering frequency every two or three days significant for biomass production and distribution. From the present results of this study it can be concluded that soil media and watering frequency improved both biomass production and distribution patterns of korarima seedlings. Hence mixed top and compost soil media in 3:1 ratio as soil media and considering water availability and environment to irrigate every two or three days interval recommended for nursery korarima seedlings.

\section{ACKNOWLEDGEMENT}

Author acknowledge Mr. Abrar Sualeh for his valuable comments and suggestions during preparation of this manuscript. 


\section{REFERENCES}

[1] James S. McDonald, Tom Ericsson and Carl-Magnus Larsson.1996 Plant nutrition, dry matter gain and partitioning at the whole-plant level. Journal of Experimental Botany. 47: $1245-1253$.

[2] Chaves, R.M., Ten-Caten, A., Pinheiro, H.A., Ribeiro, A. and Damatta, F.M. (2008) Seasonal changes in photopro- tective mechanisms of leaves from shaded and unshaded field-grown coffee (Coffea arabica L.) trees. Trees, 22, 351-361. Doi : 10.1007/s00468-007-0190-7 .

[3] CHB. 1987. Coffee Hand Book (CHB). Coffee Growers Association, Harare, Zimbabwe, Canon Press (Pvt) Ltd.

[4] Ericsson T. 1995. Growth and shootroot ratio of seedlings in relation to nutrient availability. Plant and Soil 168/169:205-14.

[5] Eyob, S.; Appelgren, M.; Rohloff, J.; Tsegaye, A.; Messele, G. 2007. Chemical composition of essential oils from fresh plant parts of korarima (Aframomum corrorima) cultivated in the high land of Southern Ethiopia. J. Essent. Oil Res. 19: 372-375.

[6] Eyob S. 2009 Promotion of seed germination, subsequent seedling growth and in vitro propagation of korarima (Aframomum corrorima Braun P.CM.Jansen.) J. Medicinal Plants Research 3(9): 652-659.

[7] Girma, H-M., T. Digafie, E. Edossa, Y-B. Belay and G. Weyesa, 2008. Spices Research Achievements, (Rev. ed.). Ethiopian Institute of Agricultural Research. Addis Ababa, Ethiopia.

[8] Institute of Agricultural Research, 1996. Recommended Production Technologies for Coffee and Associated Crops. Jimma Agricultural Research Center, Jimma, Ethiopia pp: 17.

[9] Jansen PCM .2002. Aframomum corrorima (Braun) P.C.M. Jansen. Record from protabase. In: Oyen LPA, Lemmens RHMJ (eds) PROTA (Plant Resources of Tropical Africa/Ressources végétales de l'Afrique tropicale). Wageningen, Netherlands.

[10] Moacyr B. and Dias Filho. 1995. Root and shoot growth in response to soil drying in four amazonian weedy species.

[11] Mohammed worku .2004. Rresponse of seedlings of Arabica coffee (Coffea arabica 1.) cultivars to soil water deficit.. An M. Sc. Thesis Presented to Graduate Studies of Alemaya university, Alemaya, Ethiopia.

[12] Neelam, A.and M.Ishtiaq. 2001. Response of Eucalyptus camaldulensis seedlings to different soil media. Sarhad J. Agric. 17(1):75-79.

[13] Ravindran, P.N., M. Shylaja and N.K. Babu, 2002. pp. 330-340. False cardamoms. In: avindran, P.N. and K.J. Madhusoodanan, (eds). Cardamom: The Genus Ellettaria. CRC Press, Kerala, India.

[14] Raviraja Shetty, G., Kusuma, M. V., Venkatesha, J. and Srinivasa, V.2014. Influence of integrated nutrient management on dry matter production and flowering in davana (artemisia pallens wall.) .International Journal of Development Research Vol. 4(3): 760762.

[15] R.Bras.Fisiol .1995.Root and shoot growth in response to soil drying in four amazonian weedyspecies. Veg. 7(1):53-59.

[16] .SAS (Statistical Analysis System), 2008. (Version 9.2). SAS Institute, Cary, NC. USA.

[17] Setter, T. L. 1992. Assimilate allocation in response to water deficit stress. International Crop Science. pp. 733-735. Crop Science of America, Inc., Madson, Wisconsin, USA.

[18] Simon A. Mng'omba1, Festus K. Akinnifesil, Gudeta Sileshil, Oluyede C. Ajayil, Betserai I. Nyoka1 and Ramni Jamnadass.2011. Water application rate and frequency affect seedling survival and growth of Vangueria infausta and Perseaamericana: African Journal of Biotechnology Vol. 10(9). 
[19] Taye, K. and Burkhardt, J. (2008) Ecophysiology of wild Coffea arabica populations in the montane rainforests of Ethiopia. Proceedings of a National Workshop, Four Decades of Coffee Research and Development in Ethiopia,14-17August 2007, Addis Ababa (Ghion Hotel),140-149.

[20] Taye Kufa . 2012. Biomass production and distribution in seedlings of Coffea arabica genotypes under contrasting nursery environments in southwestern Ethiopia. Agricultural Sciences. Vol.3 (6): 835-843.

[21] Tesfaye Shimber. G., Mohad.Razi Ismail, H. Kausar,M.Marziah and M,F.Ramlan. 2013. Plant water relations,crop yield and quality in Coffee(coffee Arabica L) as Influenced by partial root zone drying and deficit irrigation.AJCS(g) : 1361-1368.

[22] Wintgens, J.N. 2004 Coffee: Growing, processing, sus-tainable production. A guide for growers, traders, and re-searchers. WILEY-VCH Verlag GmbH and Co. KGaA, Weinheim. 